\title{
Study of the volatile compounds from plum (Prunus domestica L. cv. Horvin) and estimation of their contribution to the fruit aroma
}

\author{
Estudo de compostos voláteis de ameixa (Prunus domestica L. cv. Horvin) \\ e estimativa da sua contribuição ao aroma
}

Jorge Antonio $\mathrm{PINO}^{1 *}$, Clara Elizabeth QUIJANO²

\begin{abstract}
Simultaneous Distillation-Extraction (SDE) and headspace-solid phase microextraction (HS-SPME) combined with GC-FID and GC-MS were used to analyze volatile compounds from plum (Prunus domestica L. cv. Horvin) and to estimate the most odor-active compounds by application of the Odor Activity Values (OAV). The analyses led to the identification of 148 components, including 58 esters, 23 terpenoids, 14 aldehydes, 11 alcohols, 10 ketones, 9 alkanes, 7 acids, 4 lactones, 3 phenols, and other 9 compounds of different structures. According to the results of SDE-GC-MS, SPME-GC-MS and OAV, ethyl 2-methylbutanoate, hexyl acetate, (E)-2-nonenal, ethyl butanoate, (E)-2-decenal, ethyl hexanoate, nonanal, decanal, $(E)$ - $\beta$-ionone, $\gamma$-dodecalactone, $(Z)$-3-hexenyl acetate, pentyl acetate, linalool, $\gamma$-decalactone, butyl acetate, limonene, propyl acetate, $\delta$-decalactone, diethyl sulfide, $(E)$-2-hexenyl acetate, ethyl heptanoate, $(Z)$-3-hexenol, $(Z)$-3-hexenyl hexanoate, eugenol, $(E)$-2-hexenal, ethyl pentanoate, hexyl 2-methylbutanoate, isopentyl hexanoate, 1 -hexanol, $\gamma$-nonalactone, myrcene, octyl acetate, phenylacetaldehyde, 1-butanol, isobutyl acetate, $(E)$-2-heptenal, octadecanal, and nerol are characteristic odor active compounds in fresh plums since they showed concentrations far above their odor thresholds.
\end{abstract}

Keywords: plum; Prunus domestica; flavour; compound; volatiles.

\section{Resumo}

As técnicas de extração-destilação simultâneas (SDE) e de headspace-microextração em fase sólida (HS-SPME) combinadas com GC-FID e GC-MS foram usadas para analisar compostos voláteis da ameixa (Prunus domestica L. cv. Horvin) e para estimar os compostos de aroma mais ativos, pela aplicação de valores de atividade olfativa (OAV), considerando os compostos voláteis presentes no headspace da fruta. As análises levaram à identificação de 148 componentes, incluindo 58 ésteres, 23 terpenoides, 14 aldeídos, 11 álcoois, 10 cetonas, 9 alcanos, 7 ácidos, 4 lactonas, 3 fenóis e 9 outros compostos de diferentes estruturas. De acordo om os resultados de SDE-GC-MS, SPME-GC-MS e OAV, 2-metilbutanoato de etila, acetato de hexila, (E)-2-nonenal, butanoato de etila, (E)-2-decenal, hexanoato de etila, nonanal, decanal, (E)-b-ionona, $\gamma$-dodecalactona, acetato de (Z)-3-hexenila, acetato de pentila, linalool, $\gamma$-decalactona, acetato de butila, limoneno, acetato de propila, $\delta$-decalactona, sulfeto de dietila, acetato de $(E)$-2-hexenila, heptanoato de etila, $(Z)$-3-hexenol, hexanoato de $(Z)$-3-hexenila, eugenol, (E)-2-hexenal, pentanoato de etila, hexil 2-butanoato de metila, hexanoato de isopentila, 1-hexanol, $\gamma$-nonalactona, mirceno, acetato de octila, fenilacetaldeído, 1-butanol, acetato de isobutila, $(E)$-2-heptenal, octadecanal, e nerol são compostos odoríficos característicos em ameixas frescas, já que foram encontrados em concentrações muito acima dos seus limiares de precepção olfativa.

Palavras-chave: ameixa; Prunus domestica; aroma; compostos voláteis.

\section{Introduction}

Like many stone fruits, plums (Prunus domestica L., Rosaceae) are appreciated by consumers all over the world and, consequently, have gained great economic importance. The fruits are presently cultivated in all temperate regions of the world. The crop is either marketed fresh or used as dried fruit and to produce juice. It is also commonly used to make jams and other recipes or fermented to produce wine and brandy. Apart from color, sweetness, and texture, plums are especially popular for their characteristic aroma. In Colombia, plum is commonly named as "ciruela calentana", and it is typical of the region of Cundinamarca.

Studies of the volatile composition of fresh plums found that the esters are qualitatively and quantitatively the most important class of compounds (CROUZET et al., 1990). Other major volatile constituents of fresh plums are alcohols or carbonyl compounds depending on the cultivar and on the methodology used for the extraction of the volatile compounds. Nonanal, 1-hexanol, (Z)-3-hexenol, linalool, benzaldehyde, $\gamma$-octalactone, and $\gamma$-decalactone were considered as important contributors to the aroma of fresh plums (WILLIAMS; ISMAIL, 1981; CROUZET et al., 1990).

Thermal processes applied to plums induce modifications on their volatiles components, which have been described in the literature (ISMAIL et al., 1980; CROUZET et al., 1990). The thermal processing frequently induces chemical modifications of

\footnotetext{
Received $13 / 4 / 2010$

Accepted 5/1/2011 (004797)

${ }^{1}$ Instituto de Investigaciones para la Industria Alimenticia, Carretera al Guatao, Km 31/2, La Habana 19200, Cuba, e-mail: jpino@iiia.edu.cu

${ }^{2}$ Departamento de Química, Facultad de Ciencias, Universidad de los Andes, Cra. 1a Este N 18-A-10 Edif. (Q-826), Bogotá, Colombia

${ }^{*}$ Corresponding author
}

DOI: http://dx.doi.org/10.1590/S0101-20612012005000006 
the original components, leading to the production of different flavor compounds (ISMAIL et al., 1980; NUNES et al., 2008).

The significant contribution of each odorant to the characteristic flavor can be determined by the Odor Activity Value (OAV), which is the ratio of concentration to the odor threshold of the compound. Compounds with OAV greater than 1 are considered to contribute to the characteristic aroma in the food. Simultaneous distillation and solvent extraction (SDE) is an isolation technique widely used which promotes an exhaustive extraction of volatile compounds (CHAINTREAU, 2001), but rearrangements, hydrolysis or artifact compound generation during distillation by decomposition of the matrix components and impurities that may be introduced from solvents have also been reported (BOULANGER; CROUZET, 2000; CHAINTREAU, 2001). Since SDE induces the dispersion of the solid sample in the liquid phase, it is possible that not all the compounds recovered by SDE are emitted by the intact sample and/or occur in their headspace. An approach to solve these problems was proposed by Nunes et al. (2008), based on a methodology comprising a combination of sample analysis by SDE and headspace analysis by solid phase microextraction (HS-SPME).

HS-SPME is an isolation technique which saves preparation time, reduce solvent purchase and disposal costs, and can improve the detection limits with minimal artifact generation. It has been applied in a wide variety of compounds in fruits (WARDENCKI et al., 2004). Using HS-SPME, it is also possible to analyze the volatile compounds present in the headspace of fruits, which are potentially responsible for their aroma. HS-SPME technique also allows evaluating the formation of compounds during SDE due to oxidation and/or thermal reactions (NUNES et al., 2008).

Consequently, the aim of this study was to isolate the major volatile compounds from fresh plums grown in Colombia by SDE and estimate the most odor-active compounds by the application of the OAVs considering the volatile compounds present in the headspace of the fruit.

\section{Materials and methods}

\subsection{Plant material and chemicals}

Freshly harvested ripe plums cv. Horvin, grown in Cundinamarca, Colombia, were purchased from a local producer.

Authentic reference chemical compounds with purity figures above $98 \%$ were provided by Sigma-Aldrich (Milwaukee, USA) or Fluka (Neu-Ulm, Germany). Diethyl ether was purchased from Merck (Darmstadt, Germany), and it was previously redistilled and checked for purity.

\subsection{Simultaneous distillation and solvent extraction}

Two hundred grams of sliced fruits were blended with $600 \mathrm{~mL}$ of distilled water; $0.2 \mathrm{mg}$ of methyl nonanoate was added as standard, and the volatile compounds were isolated by means of simultaneous distillation-extraction using $25 \mathrm{~mL}$ of diethyl ether for 1 hour. The extract was dried over anhydrous $\mathrm{Na}_{2} \mathrm{SO}_{4}$ and concentrated to $0.6 \mathrm{~mL}$ in a Kuderna-Danish evaporator with a Vigreux column and then to $0.2 \mathrm{~mL}$ with a gentle nitrogen stream. The concentrated extract was stored in a glass screwtop vial at $-20^{\circ} \mathrm{C}$ until analysis. Two independent extractions were performed, and each extract was injected twice into the GC-FID and GC-MS.

\subsection{Headspace solid-phase microextraction}

The SPME holder and fibers were purchased from Supelco Inc. (Bellefonte, USA). Three types of fiber were used: $100 \mu \mathrm{m}$ polydimethylsiloxane (PDMS), $65 \mu \mathrm{m}$ polydimethylsiloxanedivinylbenzene (PDMS/DVB), and $75 \mu \mathrm{m}$ carboxenpolydimethylsiloxane (CAR/PDMS). The fibers were activated according to the manufacturer's instructions. Preliminary assays with PDMS were carried out in order to establish the experimental conditions for HS-SPME of plum volatiles, particularly temperature and equilibration and sampling times (results not shown). For each extraction, two halves of different fruits were placed in a $15 \mathrm{~mL}$ vial introduced in a thermostated bath adjusted to $40{ }^{\circ} \mathrm{C}$. In each extraction, the sample was kept for 15 minutes to achieve equilibrium, and afterwards the SPME fiber was exposed to the headspace of the sample to adsorb the volatiles for 30 minutes. Desorptions were performed into the GC injector for 2 minutes at $250^{\circ} \mathrm{C}$ for PDMS and PDMS/DVB fibers and at $300{ }^{\circ} \mathrm{C}$ for CAR/PDMS fiber.

\subsection{Gas Chromatography and Gas Chromatography-Mass Spectrometry}

A Hewlett-Packard series 6890 GC equipped with a $30 \mathrm{~m} \times 0.25 \mathrm{~mm} \times 0.25 \mu \mathrm{m}$ film thickness HP-5MS (Agilent, Palo Alto, CA) fused-silica capillary column with a flame ionization detector was used. Oven temperature was held at $50{ }^{\circ} \mathrm{C}$ for 2 minutes; next, it was raised to $280^{\circ} \mathrm{C}$ at $4{ }^{\circ} \mathrm{C} /$ minute and held for 10 minutes. Carrier gas (helium) flow rate was $1 \mathrm{~mL} /$ minute. The injection of SDE extract was in split mode $1: 10$, and the detector temperature was $250^{\circ} \mathrm{C}$. For HS-SPME, splitless injection mode for 2 minutes was used and desorptions for 2 minutes into the GC injector were performed at $250{ }^{\circ} \mathrm{C}$ for PDMS and PDMS/DVB fibers, or at $300^{\circ} \mathrm{C}$ for CAR/PDMS fiber. The detector temperature was $250{ }^{\circ} \mathrm{C}$. The retention times of a series of straight-chain alkanes $\left(\mathrm{C}_{8}-\mathrm{C}_{24}\right)$ were used to calculate the retention indices for all identified compounds and for reference standards.

GC-MS analyses were performed on a Hewlett-Packard series 6890 gas chromatograph linked to a HP-5973 massselective detector with a fused capillary column similar to that of GC-FID. The temperature program and carrier gas flow rate were the same as those used in GC-FID; EIMS electron energy $70 \mathrm{eV}$; ion source temperature and connection parts: $250{ }^{\circ} \mathrm{C}$. Compounds were preliminarily identified using NIST, Wiley, NBS, Adams, and in-house Flavorlib libraries, and then the identity of most of them was confirmed by the comparison of their linear retention indices with those of reference standards or published data (ADAMS, 2001). 
Estimated concentrations for all compounds were made by GC peak area comparisons of the SDE extract components with the area of a known quantity of internal standard (methyl nonanoate). The recovery of the method was determined by the method of Standard Addition applied to one sample. The analytes (butyl acetate, ethyl hexanoate, 1-hexanol, (Z)-3-hexenol, hexyl acetate, linalool, and $\delta$-decalactone) were added at different concentrations, and their average recoveries were $\sim 89-102 \%$, with relative standard deviations lower than $<10 \%$. The GC peak area data obtained by the HS-SPME analysis were used as an indirect approach to estimate the relative content of each volatile compound.

\section{Results and discussion}

The volatiles from fresh plums, isolated by extraction with diethyl ether and SDE, were evaluated by a sensory panel when a drop of the ethereal extract was sniffed on a strip of filter paper as done by perfumers. After evaporation of the solvent, the distillate evoked the characteristic odor of plum, thereby indicating that the method used for aroma isolation was appropriate.

Table 1 lists the volatile compounds identified by comparison of their mass spectra and retention indices with those of authentic samples and published data. A total of 148 volatile compounds were identified as plum fruit constituents. The quantitative data in Table 1 show that a total of $25.4 \mathrm{mg}$ of volatile compounds was obtained per kilogram of fresh fruit (excluding stone) for the plum. Previous analysis of fresh plum using SDE technique yielded 0.1 and $0.4 \mathrm{mg} \cdot \mathrm{kg}^{-1}$ for two varieties of $P$. salicina (GOMEZ et al., 1993) and $49.4 \mathrm{mg} \cdot \mathrm{kg}^{-1}$ in candied plum (P. domestica) (NUNES et al., 2008).

Esters were by far the dominant volatiles in plum. Fiftyeight esters were identified, representing $58.8 \%$ of the total compounds. Among them, butyl acetate $\left(3.8 \mathrm{mg} \cdot \mathrm{kg}^{-1}\right)$, hexyl acetate $\left(3.4 \mathrm{mg} \cdot \mathrm{kg}^{-1}\right)$, propyl acetate $\left(1.0 \mathrm{mg} \cdot \mathrm{kg}^{-1}\right)$, ethyl butanoate $\left(0.8 \mathrm{mg} \cdot \mathrm{kg}^{-1}\right)$, and hexyl hexanoate $\left(7.2 \mathrm{mg} \cdot \mathrm{kg}^{-1}\right)$ were the most abundant of this class. These compounds were detected highly above their odor thresholds, except for hexyl hexanoate. Esters are important aroma constituents of fruits, contributing to the fruity aroma notes. According to the studies of Williams and Ismail (1981), P. domestica and ethyl butanoate are very important in the aroma of European plums. Quantitatively, esters are the major components of the volatile composition of fresh plums (CROUZET et al., 1990). Studies on Japanese plum $(P$. salicina) indicated that esters were also the main volatile constituents from this fruit (FORREY; FLATH, 1974; GOMEZ et al., 1993).

Alcohols accounted for $3.7 \mathrm{mg} \cdot \mathrm{kg}^{-1}$ of fruit, representing $14.4 \%$ of the total compounds quantified. Hexanol $\left(1.7 \mathrm{mg} \cdot \mathrm{kg}^{-1}\right)$ was the most abundant of the eleven alcohols recovered, and this compound was detected highly above its odor threshold. Hexanol was also reported as the major alcohol in Japanese plum (FORREY; FLATH, 1974; GOMEZ et al., 1993). We must stress that benzyl alcohol and 2-phenylethanol were not detected, which were previously found in candied plum (NUNES et al., 2008), even though we specifically looked for these aromatic alcohols.
Lactones, such as intramolecular esters of 4- and 5-hydroxy acids, were the third dominant class of compounds $(10.2 \%$ of the total compounds quantified). Among them, $\delta$-decalactone $\left(1.2 \mathrm{mg} \cdot \mathrm{kg}^{-1}\right)$ predominated, and it was detected above its odor threshold. The other three $\gamma$-lactones identified in the fruit were also detected above their odor thresholds. These compounds, particularly $\gamma$-lactones, are important compounds in terms of their contribution to the aroma and, in general, present fruity odor descriptors. Utilizing crosses between $P$. salicina and P. americanum, Horvat et al. (1992) found that lactones were also a major class of volatile compounds in southeastern American plums. Previous studies reported $\gamma$-dodecalactone as the major lactone in Japanese plum (P. salicina) (GOMEZ et al., 1993) and candied plum (P. domestica) (NUNES et al., 2008).

Terpenes accounted for $1.5 \mathrm{mg} \cdot \mathrm{kg}^{-1}$, representing only $6.0 \%$ of the total volatile compounds. Linalool, limonene, and a-terpineol were the dominant components and the first two were detected above their odor thresholds. These compounds have already been identified in fresh plums (CROUZET et al., 1990; WILLIAMS; ISMAIL, 1981), and both alcohols were reported as the major in their terpene class in candied plum (NUNES et al., 2008). The monoterpenols were reported as volatile constituents of fruits responsible for a wide spectrum of very pleasant aromas (BELITZ et al., 2004). According to the studies of Williams and Ismail (1981) with Prunus domestica, linalool is very important in the aroma of European plums.

Aldehydes and ketones accounted for 0.9 and $0.3 \mathrm{mg} \cdot \mathrm{kg}^{-1}$ of pulp respectively, representing together $4.9 \%$ of the total composition. Nonanal (0.3 mg. $\left.\mathrm{kg}^{-1}\right)$ and (3E)-4-(2,6,6-trimethyl1,3-cyclohexadien-1-yl)-3-buten-2-one ( $\left.0.08 \mathrm{mg} \cdot \mathrm{kg}^{-1}\right)$ were the major constituents from each group. Nonanal was detected highly above its odor threshold, and its presence was related to the composition of the skin, which is very rich in waxes. This aldehyde is a characteristic constituent of skin waxes of plums having a fragrant, woody-like aroma (ISMAIL et al., 1981; WILLIAMS; ISMAIL, 1981). The odor threshold of the identified ketone is unknown; thus their contribution to the aroma could not be evaluated. These two ketones are reported for the first time as constituents of fresh plum, and as many other identified ketones, e.g. (E)- $\beta$-damascenone, $(E)$ - $\alpha$-ionone, and $(E)-\beta$-ionone they can be regarded as product of carotenoid metabolism (OHLOFF, 1978).

Acids, alkanes, and phenols accounted for $0.5,0.4$, and $0.04 \mathrm{mg} \cdot \mathrm{kg}^{-1}$ of pulp respectively, representing together $4 \%$ of the total composition. Hexadecanoic acid $\left(0.2 \mathrm{mg} \cdot \mathrm{kg}^{-1}\right)$, decane $\left(0.1 \mathrm{mg} \cdot \mathrm{kg}^{-1}\right)$, and eugenol $\left(0.02 \mathrm{mg} \cdot \mathrm{kg}^{-1}\right)$ predominated within these groups. However, only eugenol was detected above its odor threshold. Alkanes probably contribute little to the aroma because they generally have high odor thresholds.

Contrary to other reports on plum (WILLIAMS; ISMAIL, 1981; CROUZET et al., 1990; GOMEZ et al., 1993), 2-furfural and other furans, known to be thermal degradation products of carbohydrates, were found to be absent or in minor amounts. This result confirmed that the method used for aroma isolation was appropriate. 
Table 1. Volatile composition of fresh plum and their aroma contribution.

\begin{tabular}{|c|c|c|c|c|c|c|c|c|}
\hline \multirow[t]{2}{*}{ Compound } & \multirow[t]{2}{*}{$\mathrm{ID}^{\mathrm{a}}$} & \multirow[t]{2}{*}{$\mathrm{KI}^{\mathrm{b}}$} & \multirow{2}{*}{$\begin{array}{c}\text { SDE } \\
\left(\mu \mathrm{g} \cdot \mathrm{kg}^{-1}\right)\end{array}$} & \multicolumn{3}{|c|}{ HS-SPME } & \multirow{2}{*}{$\begin{array}{c}\mathrm{OT}^{\mathrm{d}} \\
\left(\mu \mathrm{g} \cdot \mathrm{kg}^{-1}\right)\end{array}$} & \multirow[t]{2}{*}{$\mathrm{OAV}^{\mathrm{e}}$} \\
\hline & & & & PDMS & $\begin{array}{l}\text { PDMS/ } \\
\text { DVB }\end{array}$ & $\begin{array}{l}\text { CAR/ } \\
\text { PDMS }\end{array}$ & & \\
\hline \multicolumn{9}{|l|}{ Acids } \\
\hline 3-methylbutanoic acid & A & 887 & $\operatorname{tr}$ & - & $\mathrm{x}$ & - & 130 & $<1$ \\
\hline hexanoic acid & A & 1002 & $\operatorname{tr}$ & - & $\mathrm{x}$ & - & 890 & $<1$ \\
\hline pentadecanoic acid & A & 1879 & 79.3 & - & - & $\mathrm{x}$ & 10000 & $<1$ \\
\hline hexadecanoic acid & $\mathrm{A}$ & 1990 & 258.8 & $\mathrm{x}$ & $\mathrm{x}$ & $\mathrm{x}$ & 10000 & $<1$ \\
\hline \multicolumn{9}{|l|}{ Alcohols } \\
\hline 1-butanol & $\mathrm{A}$ & 653 & 900.6 & - & $\mathrm{x}$ & $\mathrm{x}$ & 500 & 1.8 \\
\hline 2-methylbutan-1-ol & $\mathrm{A}$ & 742 & 288.2 & - & $\mathrm{x}$ & $\mathrm{x}$ & 300 & $<1$ \\
\hline 2-butoxyethanol & A & 909 & 20.4 & - & $\mathrm{x}$ & - & $n d^{\mathrm{f}}$ & nd \\
\hline 1-octanol & A & 1068 & 37.5 & - & $\mathrm{x}$ & $\mathrm{x}$ & 190 & $<1$ \\
\hline 1-hexadecanol & $\mathrm{B}$ & 1875 & 49.2 & - & $\mathrm{x}$ & - & 750 & $<1$ \\
\hline 1-octadecanol & B & 2078 & 126.7 & - & $\mathrm{x}$ & $\mathrm{x}$ & 870 & $<1$ \\
\hline phytol & $\mathrm{B}$ & 2112 & $\operatorname{tr}$ & - & - & - & nd & nd \\
\hline \multicolumn{9}{|l|}{ Aldehydes } \\
\hline hexanal & $\mathrm{A}$ & 802 & $\operatorname{tr}$ & $\mathrm{x}$ & - & $\mathrm{x}$ & 4.5 & $<1$ \\
\hline (E)-2-hexenal & A & 855 & 72.0 & $\mathrm{x}$ & - & $\mathrm{x}$ & 17 & 4.2 \\
\hline heptanal & $\mathrm{A}$ & 905 & $\operatorname{tr}$ & $\mathrm{x}$ & - & - & 3 & $<1$ \\
\hline (E)-2-heptenal & A & 955 & 17.5 & $\mathrm{x}$ & - & - & 13 & 1.3 \\
\hline benzaldehyde & $\mathrm{A}$ & 960 & 32.1 & $\mathrm{x}$ & - & $\mathrm{x}$ & 350 & $<1$ \\
\hline hexadecanal & $\mathrm{B}$ & 1827 & 44.9 & $\mathrm{x}$ & - & - & 75 & $<1$ \\
\hline octadecanal & $\mathrm{B}$ & 2030 & 133.1 & $\mathrm{X}$ & - & - & 100 & 1.3 \\
\hline \multicolumn{9}{|l|}{ Alkanes } \\
\hline nonane & $\mathrm{A}$ & 900 & 17.3 & $\mathrm{X}$ & - & - & nd & nd \\
\hline decane & $\mathrm{A}$ & 1000 & 161.8 & $\mathrm{X}$ & - & - & nd & nd \\
\hline tridecane & A & 1300 & 24.2 & $\mathrm{X}$ & - & - & nd & nd \\
\hline tetradecane & $\mathrm{A}$ & 1400 & 29.8 & $\mathrm{X}$ & - & - & nd & nd \\
\hline pentadecane & A & 1500 & 8.1 & $\mathrm{X}$ & - & - & nd & nd \\
\hline hexadecane & $\mathrm{A}$ & 1600 & 86.7 & $\mathrm{X}$ & - & - & nd & nd \\
\hline heptadecane & A & 1700 & 32.3 & $\mathrm{X}$ & - & - & nd & nd \\
\hline nonadecane & $\mathrm{A}$ & 1900 & 22.6 & $\mathrm{X}$ & - & - & nd & nd \\
\hline tetracosane & $\mathrm{A}$ & 2400 & 45.8 & $\mathrm{x}$ & - & - & nd & nd \\
\hline \multicolumn{9}{|l|}{ Esters } \\
\hline ethyl acetate & $\mathrm{A}$ & 605 & 542.3 & $\mathrm{x}$ & $\mathrm{x}$ & $\mathrm{x}$ & 5000 & $<1$ \\
\hline propyl acetate & $\mathrm{A}$ & 707 & 1040.8 & $\mathrm{x}$ & $\mathrm{x}$ & $\mathrm{x}$ & 54 & 19 \\
\hline isobutyl acetate & $\mathrm{A}$ & 768 & 92.6 & $\mathrm{x}$ & $\mathrm{x}$ & $\mathrm{x}$ & 66 & 1.4 \\
\hline ethyl butanoate & A & 805 & 846.7 & $\mathrm{x}$ & $\mathrm{x}$ & $\mathrm{x}$ & 1 & 847 \\
\hline butyl acetate & $\mathrm{A}$ & 811 & 3762.3 & $\mathrm{x}$ & - & $\mathrm{x}$ & 69 & 55 \\
\hline ethyl 2-methylbutanoate & $\mathrm{A}$ & 846 & 11.0 & $\mathrm{x}$ & - & $\mathrm{x}$ & 0.006 & 1837 \\
\hline ethyl pentanoate & A & 901 & 20.7 & $\mathrm{x}$ & - & $\mathrm{x}$ & 5 & 4.1 \\
\hline
\end{tabular}


Table 1. Continued...

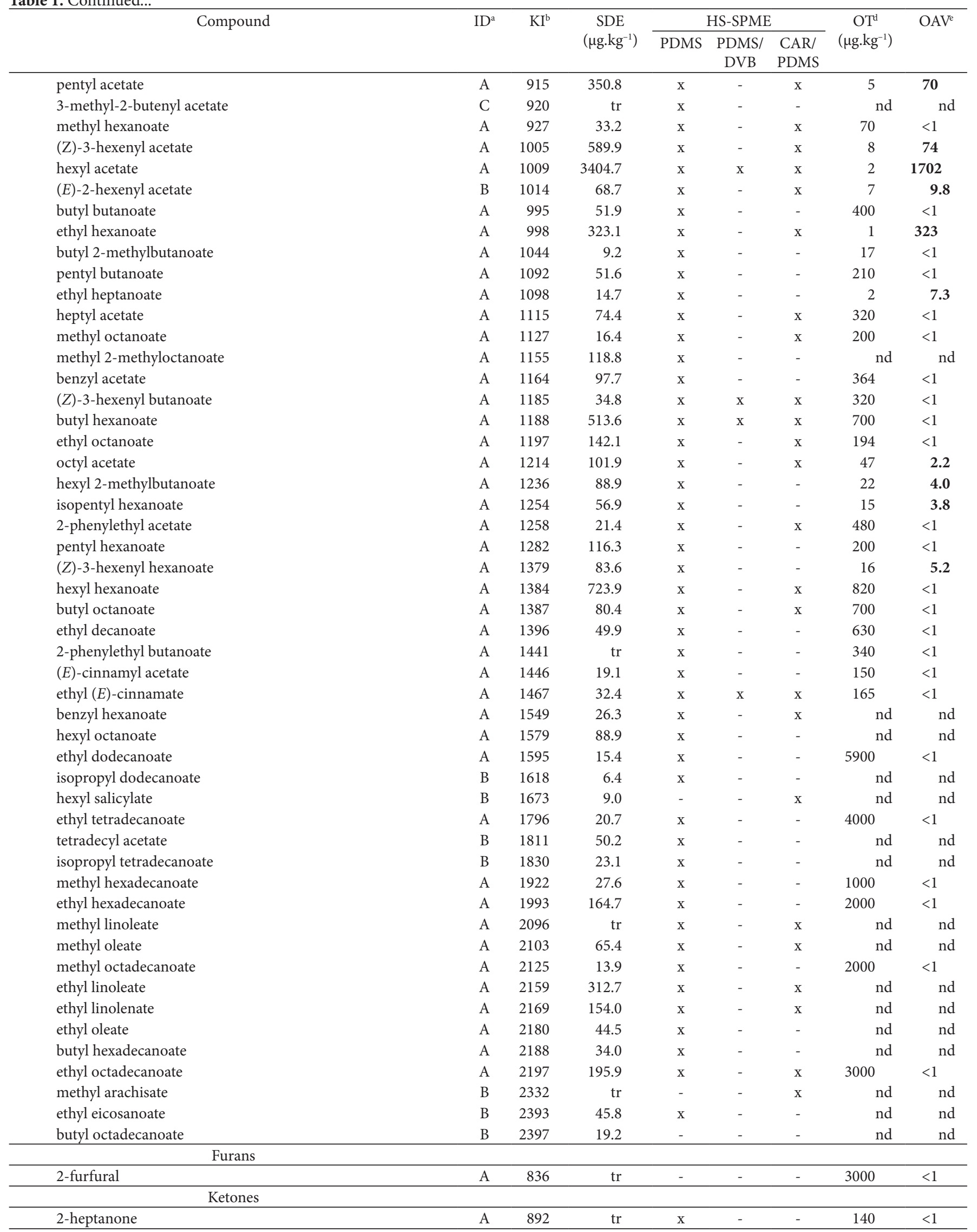


Table 1. Continued...

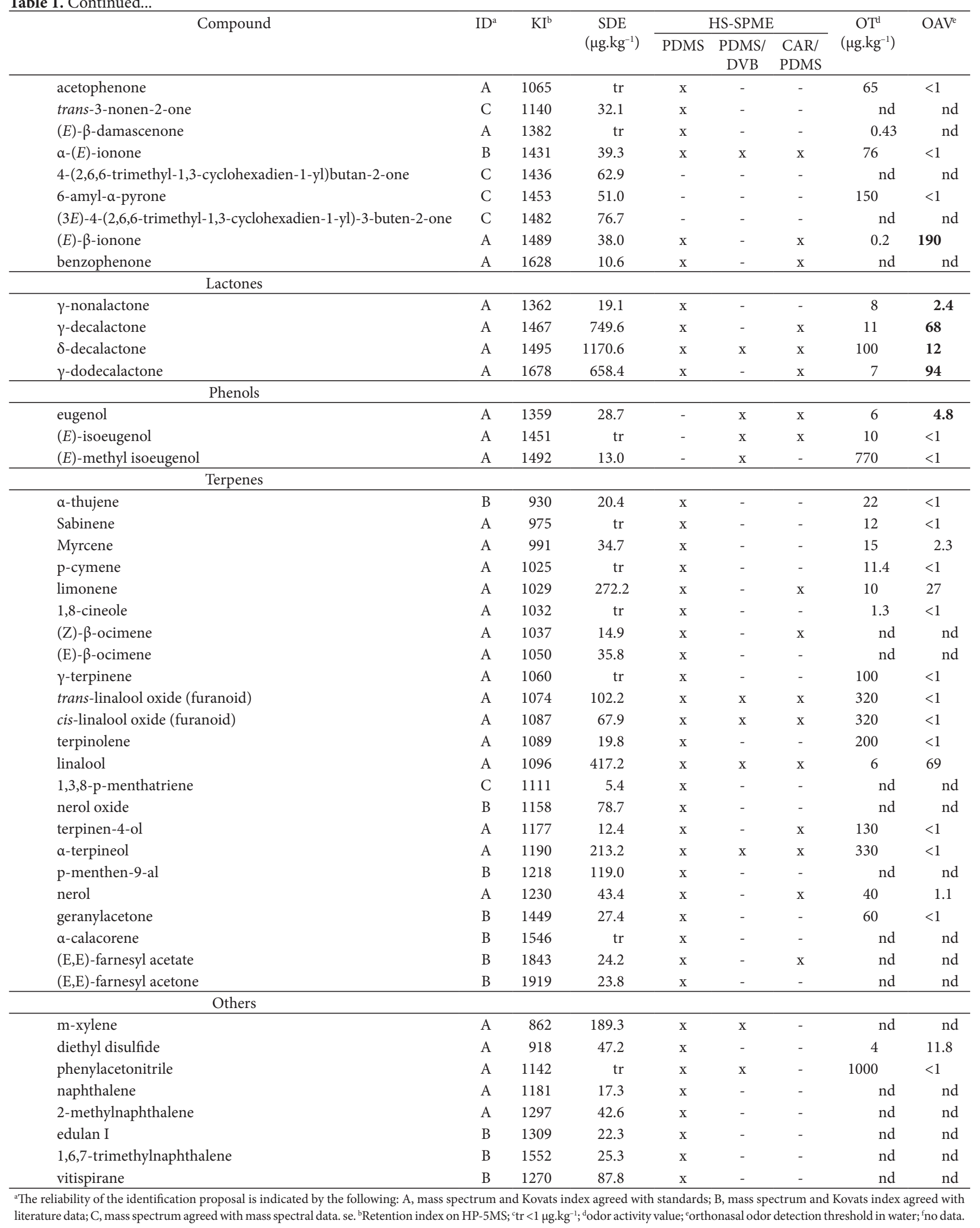


In the group of $\mathrm{S}$ and $\mathrm{N}$ compounds, two compounds were identified for the first time as constituents of fresh plum: diethyl disulfide $\left(0.05 \mathrm{mg} . \mathrm{kg}^{-1}\right)$ and phenylacetonitrile $\left(<0.005 \mathrm{mg} . \mathrm{kg}^{-1}\right)$. Only diethyl disulfide was detected above its odor threshold.

In order to determine the volatile compounds in the headspace of the plum, the HS-SPME technique was used with three fibers of different polarities (Table 1). A comparison between the SDE and HS-SPME data indicates that great differences were observed. These results are explained based on the characteristics of each extraction method used. The SDE is an exhaustive method, in which the plum was completely dispersed in hot water, and volatiles were steam distilled and extracted with diethyl ether; consequently, higher recoveries are obtained. Furthermore, the conditions of the SDE method may lead to artifacts compounds generation. On the other hand, the HS-SPME method is a non-exhaustive procedure with mild conditions, but it is specific depending of the type of fiber used. For this reason, three fibers of different polarities were used in the present study. Only four volatile compounds were not present in any of the fibers tested: 3-(2,6,6-trimethyl1-cyclohexen-1-yl)-2-propenal; 4-(2,6,6-trimethyl-1,3cyclohexadien-1-yl)butan-2-one; 6-amyl- $\alpha$-pyrone, and (3E)-4(2,6,6-trimethyl-1,3-cyclohexadien-1-yl)-3-buten-2-one. These results suggest that during the SDE some reactions originating these compounds have occurred.

Table 1 also lists the orthonasal odor detection threshold in water and the OAV for several plum volatiles. Although it is known that the odor thresholds might be influenced by nonvolatile fruit compounds, water is the main constituent of plums. If a compound has an $\mathrm{OAV} \geq 1$, it will contribute significantly to the overall fruit odor. If we look at the threshold concentration of a compound as a separate quantity, the OAV for that compound gives the number of threshold concentrations of that compound present in the fruit. The probability of a compound odor being detected should be greater in the same degree of its OAVs increase. This value should then give some indication of the importance of that compound in the overall odor. However, at least two simplifications of this concept have to be analyzed thoroughly: the assumption that the perceived intensity is proportional to the OAV and the frequent use of thresholds determined in model media other than the proper food. Despite these limitations, the OAV concept is still considered a very useful tool in aroma research.

Of the 148 constituents identified in plums, only 38 compounds had concentrations higher than their odor thresholds $(\mathrm{OAV}>1)$. The highest $\mathrm{OAV}$ were calculated for ethyl 2-methylbutanoate (1837), hexyl acetate (1702), and (E)2-nonenal (1485). Ethyl 2-methylbutanoate has a green-fruity odor, reminiscent of the peels of unripe plums; hexyl acetate has a sweet-fruity berry, and pear-like odor, while (E)-2-nonenal has a waxy and slightly green odor. Relatively high odor activity values were also calculated for ethyl butanoate (847), (E)-2decenal (357), ethyl hexanoate (323), nonanal (300), decanal (260), and (E)- $\beta$-ionone (190) with OAVs between 100 and 900. With odor activity values between 10 and 100, $\gamma$-dodecalactone, (Z)-3-hexenyl acetate, pentyl acetate, linalool, $\gamma$-decalactone, butyl acetate, limonene, propyl acetate, $\delta$-decalactone, and diethyl sulfide should also contribute to plum aroma. On the other hand, the concentrations of (E)-2-hexenyl acetate, ethyl heptanoate, $(Z)$-3-hexenol, $(Z)$-3-hexenyl hexanoate, eugenol, (E)-2-hexenal, ethyl pentanoate, hexyl 2-methylbutanoate, isopentyl hexanoate, 1 -hexanol, $\gamma$-nonalactone, myrcene, octyl acetate, phenylacetaldehyde, 1-butanol, isobutyl acetate, $(E)$-2heptenal, octadecanal, and nerol were only slightly above their threshold values.

The $\mathrm{C}_{6}$ compounds and related esters have earlier been proposed as important to the plum aroma; hexanal, when diluted, has been described as having a plum-like aroma (WILLIAMS; ISMAIL, 1981). Nonanal, linalool, $\gamma$-decalactone and $(E)-\beta$-ionone have also been described as contributors to the aroma of fresh plums (WILLIAMS; ISMAIL, 1981; CROUZET et al., 1990). However, the present study showed that many volatile compounds were, for the first time, found to be potential contributors to the aroma of fresh plums.

Numerous other plum constituents are present at or slightly above their odor detection thresholds and probably contribute to plum aroma. Since the odor detection thresholds of some volatiles have not been determined, their contribution to plum aroma is still unknown. Sensory studies with aroma models and omission experiments need to be conducted to determine the actual contribution of those volatiles to plum aroma.

\section{Conclusions}

According to the results of SDE-GC-MS, SPME-GC-MS and OAV, ethyl 2-methylbutanoate, hexyl acetate, (E)-2nonenal, ethyl butanoate, $(E)$-2-decenal, ethyl hexanoate, nonanal, decanal, $(E)$ - $\beta$-ionone, $\gamma$-dodecalactone, $(Z)$-3-hexenyl acetate, pentyl acetate, linalool, $\gamma$-decalactone, butyl acetate, limonene, propyl acetate, $\delta$-decalactone, diethyl sulfide, $(E)$ 2-hexenyl acetate, ethyl heptanoate, $(Z)$-3-hexenol, $(Z)$-3hexenyl hexanoate, eugenol, $(E)$-2-hexenal, ethyl pentanoate, hexyl 2-methylbutanoate, isopentyl hexanoate, 1-hexanol, $\gamma$-nonalactone, myrcene, octyl acetate, phenylacetaldehyde, 1-butanol, isobutyl acetate, (E)-2-heptenal, octadecanal, and nerol are characteristic odor active compounds in fresh plums since they showed concentrations far above their odor thresholds.

\section{References}

ADAMS, R. P. Identification of Essential Oil Components by Gas Chromatography/Quadrupole Mass Spectroscopy. Carol Stream: Allured Publishing Co., 2001.

BELITZ, H-D. et al. Food Chemistry. Berlin: Springer-Verlag, 2004.

BOULANGER, R.; CROUZET, J. Free and bound flavour components of Amazonian fruits: 2. Cupuacu volatile compounds. Flavour and Fragrance Journal, v. 15, n. 4, p. 251-257, 2000. http:// dx.doi.org/10.1002/1099-1026(200007/08)15:4\%3C251::AIDFFJ905\%3E3.0.CO;2-2

CHAINTREAU, A. Simultaneous distillation-extraction: From birth to maturity - review. Flavour and Fragrance Journal, v. 16, n. 2, p. 136-148, 2001. http://dx.doi.org/10.1002/ff.967

CROUZET, J. et al. Stoned fruit: Apricot, plum, peach, cherry. In: MORTON, I. D.; MACLEOD, A. J. (Eds.). Food flavours. 
Amsterdam: Elsevier Science Publishers B.V., 1990. part C:The flavour of fruits, p. 43-91.

FORREY, R.; FLATH, R. Volatile components of Prunus salicina, var. Santa Rosa. Journal of Agricultural and Food Chemistry, v. 22, p. 496-498, 1974. http://dx.doi.org/10.1021/jf60193a021

GOMEZ, E. et al. Volatile compounds in apricot, plum, and their interspecific hybrids. Journal of Agricultural and Food Chemistry, v. 41, p. 1669-1676, 1993. http://dx.doi.org/10.1021/jf00034a029

HORVAT, R. et al. Comparison of the volatile compounds from several commercial plum cultivars. Journal of Science and Food Agriculture, v. 60, p. 21-23, 1992. http://dx.doi.org/10.1002/ jsfa.2740600105

ISMAIL, H. M. M. et al. The flavor components of plum - An investigation into the volatile components of canned plums. Zeitschrift für Lebensmittel-Untersuchung und-Forschung, v. 171, n. 4, p. 265-268, 1980. http://dx.doi.org/10.1007/BF01042474

ISMAIL, H. et al. The flavour components of plums: an examination of the aroma Components present in the headspace above four cultivars of intact plums, Marjorie's seedling, Merton Gem, NAIO and Victoria. Journal of Science and Food Agriculture, v. 32, p. 498-502, 1981. http://dx.doi.org/10.1007/BF01042474

NUNES, C. et al. Study of the volatile components of a candied plum and estimation of their contribution to the aroma. Food Chemistry, v.111, p. 897-905, 2008. http://dx.doi.org/10.1016/j. foodchem.2008.05.003

OHLOFF, G. Recent developments in the field of naturally-occurring aroma components. In: HERZ, W., GRISEBACH, H.; KIRSBY, G. (Eds.). Progress in the Chemistry of Organic Natural Products. New York: Springer-Verlag, 1978. p. 431-527.

WARDENCKI, W. et al. A review of theoretical and practical aspects of solid-phase microextraction in food analysis. International Journal of Food Science and Technology, v. 39, p. 703-717, 2004. http:// dx.doi.org/10.1111/j.1365-2621.2004.00839.x

WILLIAMS, A. A.; ISMAIL, H. M. M. The volatile flavour components of plums and their sensory evaluation. In: SOLMS, J.; HALL, R. L. (Eds.). Criteria of Food Acceptance. Zurich: Foster Verlag, 1981. p. 333-354. 